\title{
THE RATE OF RETURN TO INVESTMENT IN EDUCATON: A Case STUdy OF LithuANia
}

\author{
Simona Potelien $\dot{e}^{*}$ \\ Zita Tamašauskiene $\dot{*}^{* *}$
}

\section{INTRODUCTION}

Education is widely accepted as one of the leading instruments for promoting economic development. Higher education is an important form of investment in human capital development. In fact, it can be regarded as a high level or a specialized form of human capital, the contribution of which

to economic development is very significant. It is rightly regarded as the "engine of development in the new world economy"1.

The literature provides evidence of the benefits of education to individuals and society. For the individual, educational attainment is a key determinant of earnings and has a significant effect on labour market outcomes ${ }^{2}$. Investment in education also delivers non-monetary benefits. Higher education is also associated with longer life expectancy, improved health, reduced participation in crime, and greater participation in civic and social life (for more educated people) etc.

The private return to education constitutes an important incentive for individuals to invest in post compulsory education. In this context the word "return" is always used in the sense of the internal rate of return. The rate of return or internal rate expresses revenues as a percentage return on the

DOI: $10.1515 /$ wrlae-2015-0014

*Faculty of Social Sciences, Siauliai University, Architektu st.1, LT-78366, Siauliai, Lithuania, e-mail: simona.ind@gmail.com

** Faculty of Social Sciences, Siauliai University, Architektu st.1, LT-78366, Siauliai, Lithuania, e-mail: zita.tamasauskiene@smf.su.lt

${ }^{1}$ Ceyda Özsoy, 'The Contribution of Higher Education to Economic Development' (8th Global Conference on Business \& Economics, Florence, Italy, October 18-19th, 2008)

$<$ http://www.academia.edu/773478/The_Contribution_of_Higher_Education_to_Economic_Development $>$ accessed 10 February 2015.

${ }^{2}$ Angel de la Fuente and Juan F. Jimeno, The private and fiscal returns to schooling and the effect of public policies on private incentives to invest in education: a general framework and some results for the EU' (2005) CESifo Working Paper 1392. 
investment. A high private return constitutes a strong incentive for individuals to invest in (further) education beyond compulsory schooling ${ }^{3}$.

Human capital theory considers individuals, not governments, as the investors in education. It is an individual who chooses to continue schooling or not. So, one of the questions asked by many university or college students is: "Is a university/college education a good investment?"

In making that decision, the individual knows that investing more time in school raises wages per unit of time. But given that a working life, or pension age, is finite, the amount of time left to participate in the labour market after further education is reduced.

Taking into account that human capital theory predicts that individuals will choose exactly the amount of time devoted to education that maximises their income over their lifetime, the question arises as to what will be the rate of return to higher education, i.e., higher education acquired. Is it worth trying, spending time and investing in higher education?

The aim of the research - to estimate the private return to education in Lithuania for the current period and compare the rate of return with data for other countries.

The object of the research - the rate of return to investment in education.

The research methods used: comparative and logical analysis and interpretation of literature, comparative analysis of statistical data, generalization method.

\section{Definition of HuMAN CAPITAL}

The concept of human capital is central to much of the research on the economic returns of education, we thus start with briefly introducing the human capital theory and the definition of human capital.

Human capital theory argues that the diversity and different levels of knowledge and skills embedded in human beings constitutes a potential source for economic growth and wealth creation. This indeed is a factor that may explain why innovative capabilities differ amongst nations, industries and regions ${ }^{4}$.

The formal concept of human capital was developed in the 1960s by a group of economists associated with the University of Chicago (Becker, 1964; Mincer, 1958, 1966; Schultz, 1962), although the idea that investment in education has a long-term economic and social payoff for the individual and society at large goes back to Adam Smith if not earlier. According to J. M. C. Alcantar ${ }^{5}$ and S. R. Sweetland $^{6}$, Adam Smith (1776) first identified a person's skills, abilities and personal knowledge as important qualities of people when considering their

\footnotetext{
3 Education at a Glance 2013 (OECD 2013) <http://www.oecd.org/edu/eag2013\%20\%28eng\%29-INAL\%2020\%20June\%202013.pdf> accessed 5 September 2014.

${ }^{4}$ Juan Manuel Corona Alcantar, 'Human capital formation. The role of science and technology policy. A case study in Mexican biotechnology sector' (DPhil thesis, Manchester Business School 2006).

${ }^{5}$ ibid.

${ }^{6}$ Scott R. Sweetland, Human Capital Theory: Foundation of a Field of Inquiry' (1996) 66 Review of Education Research 341-359.
} 
economic activities. Smith's major contribution to human capital theory was the identification of the economic value of education and apprenticeship in the acquisition of personal knowledge and skills.

Human capital can be defined in many ways. This version can be defined as the ability of an individual to generate income by having certain skillset or knowledge or as the knowledge, skills, and experience of people that make them economically productive. According T. W. Schultz", the term "human capital" has been defined as a key element in improving a firm's assets and employees in order to increase productivity as well as sustain competitive advantage. G. S. Becker proposed that human capital is the stock of knowledge, skills and abilities embedded in an individual which results from natural endowment and subsequent investment in education, training and experience ${ }^{8}$. T. O. Davenport considered that human capital was composed of four main factors: ability, behaviors, efforts and time 9 . M. Lynn proposed that human capital included the skills and abilities posessed by the employees within an organization ${ }^{10}$. Some definitions of human capital (e.g. Laroche, Merette and Ruggeri ${ }^{11}$ ) include innate abilities as well as the knowledge and skills that individuals acquire throughout their lifetimes. J. I. Nakamura defines human capital broadly as labour skills, managerial skills, and entrepreneurial and innovative abilities plus such physical attributes as health and strength $^{12}$.

Through these definitions there is a clear emphasis on human capital as the knowledge, skills and abilities of individuals, and the authors take this as the definition of the concept for the present study.

\section{INVESTMENT IN HUMAN CAPITAL}

Human capital theory provides a framework for analyzing educational investment. In human capital theory, education is an investment of current resources in exchange for future returns. Human capital theory asserts that individuals consciously choose to invest in themselves through various activities $^{13}$. Usually, this is through education and training. The standard approach assumes that the individual invests an amount of time in education, and then the return comes in the form of enhanced future earnings ${ }^{14}$, i.e. investment in education increases the individual's future earnings. Private investment in

\footnotetext{
7 Theodore W. Schultz, 'The economic importance of human capital in modernization' (1993) 1 (1) Education Economics 13-19.

${ }^{8}$ Gary. S. Becker, Human capital: A theoretical and empirical analysis, with special reference to education (New York, National Bureau of Economic Research 1964).

${ }^{9}$ Thomas O. Davenport, 'Human capital' (1999) 88 (11) Management Review 37-43.

${ }^{10}$ Mason Lynn, 'The ROI of human capital' (2002) 19 (4) HR Professional 34-45.

${ }^{11}$ Mireille Laroche, Marcel Mérette and G. C. Ruggeri, 'On the Concept and Dimensions of Human Capital in a Knowledge-Based Economy Context' (1999) XXV (1) Canadian Public Policy 87-100.

12 James I. Nakamura, 'Human Capital Accumulation in Premodern Rural Japan' (1981) 41 (2) The Journal of Economic History 263-281.

13 Maureen Woodhall, 'Human capital concepts' in M. Carnoy (ed), International encyclopedia of economics of education (Oxford, Pergamon 1995) 24-28.

${ }^{14}$ Gary S. Becker, Human capital: a theoretical and empirical analysis with special reference to education (3rd ed, Chicago, The University of Chicago Press 1993).
} 
education theoretically provides an individual with the higher lifetime income level, social status and personal freedom ${ }^{15}$. As noted by T. Qiu, according to the traditional method of calculating rates of return to investment in education, which is known as cost-benefit analysis, the analysis must commence with the calculation of all costs and benefits involved in this investment ${ }^{16}$. It is suggested that although in theory it is straightforward, the actual measurement of costs, and especially benefits is difficult to obtain. Based on this, economists have tended to concentrate on the relatively hard evidence relating to benefits that exists in most countries, which is known as the age-earnings profile, that those people with higher levels of education on average receive higher incomes throughout their working lives than people with lower levels of education ${ }^{17} 1819$.

G. Psacharopoulos ${ }^{20} 21$, R. G. Ehrenberg, R. S. Smith ${ }^{22}$, M. Carnoy ${ }^{23}$ and others have provided a model, shown in Figure 1, conceptualizing the costs and benefits of education. The horizontal axis represents the age of an individual, from birth through to retirement. The vertical axis represents earnings and costs of education. Social and private costs include foregone earnings, tuition, fees, books, and other miscellaneous costs. State subsidies for higher education, including capital, operating, and financial aid costs are also included. The net educational premium is the differential between those with college degrees and those without. I.e. by not working for four years, the university student incurs an indirect (opportunity) cost in terms of forgone earnings equal to what secondary school graduates of the same age are earning in the labour market. At the same time, the university student incurs a direct cost (private costs) equal to any tuition and incidental expenses he or she is paying for his or her studies. After graduation (say at the age of 22), the university graduate will start earning more than secondary school graduates of the same age are earning in the labour market, and the earnings advantage of the university graduate will continue over a lifetime.

\footnotetext{
${ }^{15}$ Randall K. Filer, Daniel S. Hamermesh and Albert E. Rees, The Economics of Work and Pay (6th ed, New York, HarperCollins College Publishers 1996).

16 Tian Qiu, Private returns to education: earnings, health and well-being (A Thesis Submitted for the Degree of Doctor of Philosophy University of Bath, Department of Economics and International Development 2007).

${ }^{17}$ James R. Hough, 'Educational cost-benefit analysis’ (1993) 2 Education Research Paper.

${ }^{18}$ James R. Hough, 'Educational Cost-benefit Analysis' (1994) 2(2) Education Economics 93-128.

19 James R. Hough, Educational Cost-benefit Analysis (London, Department for International Development 2000).

${ }^{20}$ George Psacharopoulos, 'Returns to Education: An Updated International Comparison` (1981) 17(3) Comparative Education 321-341.

${ }^{21}$ George Psacharopoulos, 'The value of investment in education: theory, evidence and policy' (2006) 32(2) Journal of Education Finance 113-136.

${ }^{22}$ Ronald G. Ehrenberg, Robert S. Smith, Modern Labor Economics: Theory and Public Policy (Prentice Hall 1996).

${ }^{23}$ Maritin Carnoy, 'Rates of return to education' in M. Carnoy (ed), International encyclopedia of economics of education (Oxford, Pergamon 1995) 364-379.
} 
Figure 1. Investment in higher education and returns over the life cycle

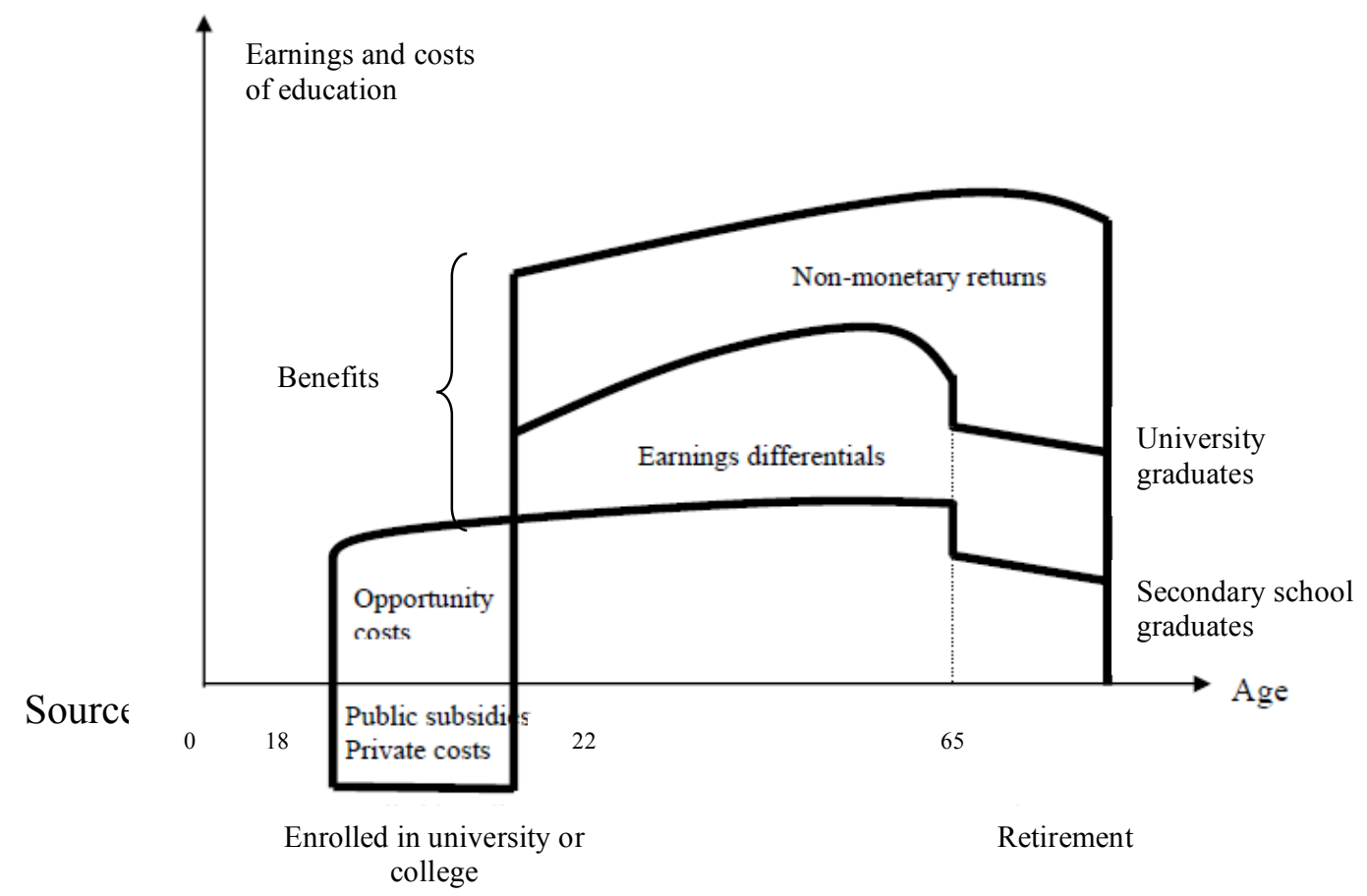

As shown in the figure 1, individuals with university (college) education earn more than those without. Therefore, the higher the education one has, the higher is the salary. Figure 1 also shows that individuals' earnings increase with age, but decrease upon reaching a certain age (say, 65 years and above). Private benefits are the individual earnings after tax, while social benefits are the incomes that a country generates from the extra tax from its citizens who earn more as a result of their higher education. But it is recognised that the benefits of higher education for individuals and for society as a whole are both monetary and nonmonetary. W. W. McMahon and A. P. Wagner describe the non-monetary returns to higher education as "those accruing later to the student following the investment made during the college years and consumption benefits enjoyed while attending college" 24 . To the individual, these may include a longer life, consumptionefficiency, and greater use of leisure time. For society, these benefits include lower crime rates, less reliance on corrections, lower health care costs, and less money spent on unemployment and welfare.

\section{Measures of Human Capital Returns. Methodology}

The measurement of human capital returns has been subject to a great deal of attention in the literature on the subject. D. Card offers a comprehensive review of the literature, as well as an extended discussion of various econometric

${ }^{24}$ Walter W. McMahon and Alan P. Wagner, 'The monetary returns to higher education: Are they worth the investment costs?' (1979) Faculty Working Paper No. 619, 5. 
issues $^{25}$. A. Stark stating that there are three main methods of estimating rates of return to investments in human capital (education), highlights Mincers' (1974), econometrical earnings function estimation, the ratio of discounted net benefits to discounted total costs, and the internal rate of return associated with the investment in education that is calculated in almost the same way as the profitability of a financial asset ${ }^{26}$.

Considering higher education as an investment, we follow classical investment theory suggesting that the net present value (NPV) or the internal rate of return (IRR) of the cash flow streams associated with higher education represent the relevant criteria in order to establish investment priorities. The NPV is the present value of the difference between the benefits of higher education and its cost. The IRR represents the discount rate that equates the present value of additional income compared to those who had the right to, but did not pursue higher education to the present value of cost (opportunity cost through foregone earnings and, under a private financing scheme, the direct cost of study). If this rate of return is higher the market interest rate at which the individual can borrow, education represents a worthwhile investment for the individual. If the private IRR is below the relevant interest rate, we can quantify an "unobservable" return component that would be necessary to make education a worthwhile investment $^{27}$.

Given the various procedures available in the literature for estimating the returns to higher education, we will evaluate the rate return of human capital using one of the main ways to calculate the rate of returns to investment in human capital, which is used in the empirical practice, - the internal rate of return (IRR), which in the literature is identified also as the "full discounting" method ${ }^{28}$ or the elaborate method (based on individual age-earnings profiles that vary over time (t)). This method can be described as follows.

The full discounting /elaborate method, which, according to R. Jamil, was developed by economists such as T. W. Schultz and G. S. Becker, requires data on age-earnings profiles by level of education ${ }^{29}$. Considering the fact that it's sometimes difficult to obtain such data, therefore, approximations are used where workers with the same educational level are grouped together and their ageearnings profiles by levels of education are recorded.

Using this method, private returns on investment are calculated by deducting the costs of education from the benefits of education. The benefits are derived by comparing the difference in earnings of an individual of a specific education level with the earnings of another working individual with similar characteristics (like

${ }^{25}$ David Card, 'Estimating the Return to Schooling: Progress on Some Persistent Econometric Problems“ (September 2001) 69(5) Econometrica 112-1160.

26 Alan Stark, Which Fields Pay, Which Fields Don't? An Examination of the Returns to University Education in Canada by Detailed Field of Study (Department of Finance, Canada 2007).

${ }^{27}$ Mark Wahrenburg and Martin Weldi, Return on Investment in Higher Education - Evidence for Different Subjects, Degrees and Gender in Germany (Discussion paper, Goethe University Frankfurt 2007).

${ }^{28}$ This method was applied by K. A. Collins and J.B. Davies (2005), D. Boothby ir G. Rowe (2002), Ch. Constantatos, E. G. West (1991), V. Dickson, W. J. Milne, D. Murrell (1996), M. Wahrenburg, M. Weldi (2007), O. Kara (2009), A. C. Harberger and S. G. Guillermo-Peon (2012) and others who were evaluating the return to investment in human capital (education) in their studies.

${ }^{29}$ Rossilah Bt. Jamil, 'Human capital: a critique' (2004) 4 Journal Kemanusiaan 10-16. 
age, gender, ability, etc.) but without such education. The costs accounted for by this method are the direct (private) costs of seeking the education such as tuitions, living costs in the university town, transport charges and so on, plus the indirect costs (opportunity costs), which are foregone earnings that individuals could have potentially earned if they not attended study. According to G. S. Becker (1993), the potential earnings of a first-year university (or college) student should be compared to that of a person who started working straight after finishing secondary school, while a second-year student with that of one who left university (college) one year after, and so on (depending on the length of education (in years) in university (college) ${ }^{30}$. The foregone earnings for the last half-year in university (or college) are compared to that of a university (college) dropout. Due to its scarcity and hence the difficulty in obtaining such data, the forgone earnings of a university (college) student are thus compared with the actual earnings of a secondary school graduate of similar age $\mathrm{e}^{31}$.

The full discounting /elaborate method or simply the rate of return can be expressed formally as:

$$
\sum_{t=1}^{n} \frac{C_{t}}{(1+r)^{t}}-\sum_{t=n+1}^{m} \frac{B_{t}}{(1+r)^{t}}=0
$$

where $C_{t}$ - opportunity costs of university degree in year $t ; B_{t}$ - benefit of university degree in year $\mathrm{t} ; \mathrm{n}$ - length of education; $(\mathrm{m}-\mathrm{n})$ - years in the workforce; and $\mathrm{r}$ - rate of return (in this expression for the rate of return it is assumed that all costs are incurred in years 1 to $n$, and benefits accrue between years $n$ and $m)^{32}$.

A. Stark ${ }^{33}$ suggest his formula, where A and B represent the earnings streams with and without the investment, respectively

$$
0=\sum_{i=1}^{N} \frac{\left(A_{i}-B_{i}-C_{i}\right)}{(1+r)^{i}}
$$

where $\mathrm{C}$ represents the private costs associated with the investment (tuition fees and non-fee costs), $\mathrm{N}$ represents the number of years between when the educational investment begins and when a person retires.

According to M. Arrazola, J. Hevia, M. Risueno and J. F. Sanz ${ }^{34}$ the rate of return to investment in education can be found by this formula:

$$
\sum_{t=-s}^{0}\left(C_{h}+W_{h-1}\right)_{t}(1+r)^{-1}=\sum_{t=1}^{\vartheta}\left(W_{h}+W_{h-1}\right)_{t}(1+r)^{-1}
$$

\footnotetext{
30 Becker (n 14).

31 Jamil (n 29).

32 Jeff Borland, Peter Dawkins, David Johnson and Ross Williams, Returns to Investment in Higher Education (The Melbourne Economics of Higher Education Research Program Report No. 1, The University of Melbourne 2000).

${ }^{33}$ Stark (n26).

${ }^{34}$ María Arrazola, José de Hevia, Marta Risueño and José Félix Sanz, 'Returns to education in Spain: some evidence on the endogeneity of schooling' (2003) 11(3) Education Economics 293-304.
} 
where s - length of education, $\vartheta$ - years in the workforce, $\mathrm{C}_{\mathrm{h}}$ - opportunity costs of university degree, $\mathrm{W}_{\mathrm{h}}$ - benefit of university degree.

In this study measuring the rate of return to investment in human capital was used this technique by formula given below (Psacharopoulos, $\mathrm{Ng}^{35}$, Psacharopoulos $^{36}{ }^{37}$, Jimenez and Patrinos ${ }^{38}$, Patrinos and Psacharopoulos ${ }^{39}$ :

$$
\sum_{t=m+1}^{n} \frac{\left(W_{U}-W_{S}\right)_{t}}{(1+r)^{t}}=\sum_{\mathrm{t}=1}^{\mathrm{m}}\left(W_{S}+C_{U}\right)_{t}(1+r)^{t}
$$

where $(r)$ is the discount rate that equates the benefits from the extra education (proxied by earnings differentials in the economy), to the sum of indirect (opportunity) costs (foregone earnings of the student while studying), and the direct resource costs of schooling (education) at a given point in time. Thus, $\left(W_{U}\right.$ $\left.-W_{S}\right)_{\mathrm{t}}$ - is the difference between a more educated person (subscript $\mathrm{U}$ ) and a less educated person (subscript $\mathrm{S}$, the control group). $W_{U}$ is the annual earnings of a more educated person. $\mathrm{C}_{\mathrm{U}}$ erepresents the direct costs of schooling (education) consisting of tuition and fees, books, etc., and $\mathrm{W}_{\mathrm{S}}$ denotes the student's foregone earnings or indirect costs 404142 .

So, this method calculates the current value of investment opportunities' cash flows and hence takes into account the time value of money (Bennouna, Meredith and Marchant ${ }^{43}$; Diacogiannis ${ }^{44}$ ). This value states that a Euro today is worth more than a Euro tomorrow. According to C. Correia and P. Cramer, this is a primary condition in the selection of investment appraisal methods. The main of advantages in using IRR is that this method is easy to understand, because returns are stated in terms of a percentage ${ }^{45}$.

The methodology for this study will consist of three steps. The first step involves calculating the direct (private) costs, including foregone earnings, tuition. Next, we compute the private benefits or wage premium, measured as the difference between the after tax earnings of university (or college) graduates and secondary school graduates. Third, the private rate of return, using the Full

${ }^{35}$ George Psacharopoulos, Ying Chu Ng, Earnings and Education in Latin America: Assessing Priorities for Schooling Investments (WPS Series No. 1056, The World Bank 1992).

${ }^{36}$ George Psacharopoulos, 'Returns to Investment in Education: A Global Update' (1994) 22(9) World Development 1325-1343.

${ }^{37}$ George Psacharopoulos, Returns to Investment in Higher Education: A European Survey, an contribution to the Higher Education Funding reform project for the European Commission (led by CHEPS 2009).

${ }^{38}$ Emmanuel Jimenez, Harry Anthony Patrinos, 'Can Cost-Benefit Analysis Guide Education Policy in Developing Countries? Policy Research Working Paper 4568 (The World Bank 2008).

${ }^{39}$ Harry Anthony Patrinos, George Psacharopoulos, 'Education. Past, Present and Future Global

Challenges' Policy Research Working Paper 5616 (The World Bank 2011).

${ }^{40}$ Psacharopoulos, $\mathrm{Ng}$ (n 35).

${ }^{41}$ Psacharopoulos (n 36).

42 Psacharopoulos (n 37).

${ }^{43}$ Karim Bennouna, Geoffrey G. Meredith and Teresa Marchant, 'Improved capital budgeting decision making: evidence from Canada' (2010) 48 (2) Management Decision 225-247.

${ }^{44}$ George P. Diacogiannis, Financial Management: A modeling approach using spreadsheets (McGraw Hill Book Company, London 1994).

${ }^{45}$ Claudia C. Correia and P. Cramer, 'An analysis of cost of capital, capital structure and capital budgeting practices: a survey of South African listed companies‘ (2008) 16 (2) Meditari Accountancy Research 3152. 
Discounting Method is measured. And finally, the last step involves comparing gathered data with analogical data in other countries.

Basic methodological assumptions, made in present study are:

- study and work: for persons aged 18 to 65 , life-time earnings under two assumptions:

$\bigcirc$ they enter the labour market with their current attainment level; or

o they remain in education, i.e. go on to study at university (or college), reach a higher attainment level, and then enter the labour market with higher earnings and employment probabilities.

- retirement: for person aged 65 and over.

\section{The Costs AND Benefits OF INVESTMENT IN EDUCATION}

The costs. In general, there are two general types of costs of investment in human capital: direct costs and indirect costs of education, which are termed as the foregone earnings in the learning process. Examined in more detail, the costs of education can be classified into these elements: (1) students' (or parents') direct costs of education; (2), individual indirect costs, (3) opportunity costs (foregone earnings), (4) state direct costs of education and (5) public indirect/ opportunity costs of education, calculated as the foregone taxes from the student foregone earnings.

Table 1. Structure of human capital investment costs in education

\begin{tabular}{|l|l|}
\hline \multicolumn{1}{|c|}{ Type of costs } & \multicolumn{1}{c|}{ Costs structure } \\
\hline \multirow{5}{*}{ Direct educational costs } & Annual tuition fee \\
\cline { 2 - 2 } & Various administrative taxes \\
\cline { 2 - 2 } & $\begin{array}{l}\text { Expenditure for books, supplies, } \\
\text { equipment }\end{array}$ \\
\hline Indirect educational costs & Expenditure on accommodation (host) \\
\cline { 2 - 2 } & Transport costs (regular trips home) \\
\cline { 2 - 2 } Opportunity cost & Additional costs for food \\
\hline & $\begin{array}{l}\text { Direct net revenue derived from } \\
\text { wages }\end{array}$ \\
\cline { 2 - 2 } & $\begin{array}{l}\text { Income from the placement } \\
\text { (investment) savings }\end{array}$ \\
\cline { 2 - 2 } & Other gains in terms of value \\
\hline
\end{tabular}

As presented in Table 1 the total actual costs of investment in educational capital is not confined, as it might seem, to the direct and indirect costs of schooling, but also opportunity costs, i.e. earnings that are lost through the option of education. 
A. Florides ${ }^{46}$, while examining the importance of education and main costs that appear in order to acquire education, besides the direct costs and indirect costs (and opportunity costs), which include the foregone earnings of not entering the labour market directly after school, (which were discussed above) identified the physical costs of studying and being examined.

In summary, it must be concluded that in order to calculate the costs of investment in human capital, the tuition, living expenses (in conjunction with the purchase of teaching aids) and foregone earnings, that appear due to the fact that the student often is not employed or is employed as a part-time worker, have to be assessed.

Note that the opportunity cost of wages was calculated according to the salary income that our graduate would have obtained if he/she had chosen to get a job and not attend university. According to data of the Lithuanian Department of Statistics, an individual that decides to invest into himself and study has lost 308 Euros/month of revenues. In order to preliminarily assess student living costs and other costs of study, the Lithuanian Department of Statistics gathered and used data about the average monetary consumption expenditure for one household member per month. Note that expenses for alcohol and tobacco were not included into students' average living expenses, because this is not directly related with studies, but related with individual habits. Housing costs and maintenance fees (it is assumed that student is living in a dormitory and does not pay separately for these services), education costs (these costs are evaluated separately, because household expenditure derives only from the average costs for all habitants). Hotel and restaurant costs were also not included into students ${ }^{6}$ average living costs. According to the calculations and assumptions made, it was found that if a student has a government grant for their studies, his/her costs for education were 6,600 Euros per year.

Another important part of the costs of investment into human capital, excluding those previously mentioned, is the tuition fee (direct educational costs). The tuition fees for the first cycle (bachelors) studies ranges from 1,100 Euros (humanities field of study areas (except philology), social science field of study areas (except psychology education and skills and public security) to 5,300 Euros (pilot training, music) per year. According to this data, average tuition fee for the first cycle studies is 2,550 Euros per year.

After evaluation of the results it can be stated that costs of investment in human capital (higher education) consists of 9,150 Euros per year.

The benefits. Education can benefit individuals in three different ways. Firstly, people are more likely to participate in the labour market; secondly, education means that individuals are likely to experience less unemployment and, finally, higher skills means that workers earn, on average, higher wages than those with lower skills ${ }^{47}$.

The calculations, in accordance with the assumptions made, enabled the assessment of possible additional revenues, which showed that individual with a

\footnotetext{
${ }^{46}$ Andros Florides, 'Human Capital: A Theoretical Outline' [1995] Student Economic Review (Trinity College, Dublin 1995).

${ }^{47}$ Commission, Study on 'The returns to various types of investment in education and training', DG EAC projects in "Economics of education" (2005).
} 
higher education (i.e., who graduated at least the first cycle studies) has earned on average an additional 366 Euros per month more than an individual without a higher education. I.e., the difference between the private net (excluding taxes) earnings of individuals with different level of education is about 4,400 Euros per year.

\section{Calculating the Private Returns. Results and INTERNATIONAL COMPARISON}

The full discounting /elaborate method measures the private benefits of education in monetary terms i.e. calculating the extra income individuals who earn more as a result of higher levels of education.

After evaluation of additional income, appearing to be due to higher human capital (i.e., higher education acquired), and the direct and indirect (alternative) costs of investment in human capital it was found that the rate of return to investment in human capital, for those individuals whose studies are financed by the government, is 13 percent.

The calculations of the rate of return to investment in human capital has showed that in case the individual has to pay for higher education himself individual rate of return into human capital is 9,8 percent. Therefore the tuition fee is increasing direct costs which negatively affect the rate of return.

It must be noted that rate of return on human capital differs among countries. While conducting this research - OECD data was used. Figure 2 describes the private rate of return computed by OECD experts on education in the annual report called Education at a Glance 2013. The rates were computed on the data from year 2009. The private rate of return mainly depends on the level of wages and wage premium for tertiary-educated persons and secondly on the tuition fees (if they are collected), see Figure 2. It should be noted that OECD tuition fees are not taken into the rate of return consideration.

Figure 2. Private rate of return to investment in human capital in European countries

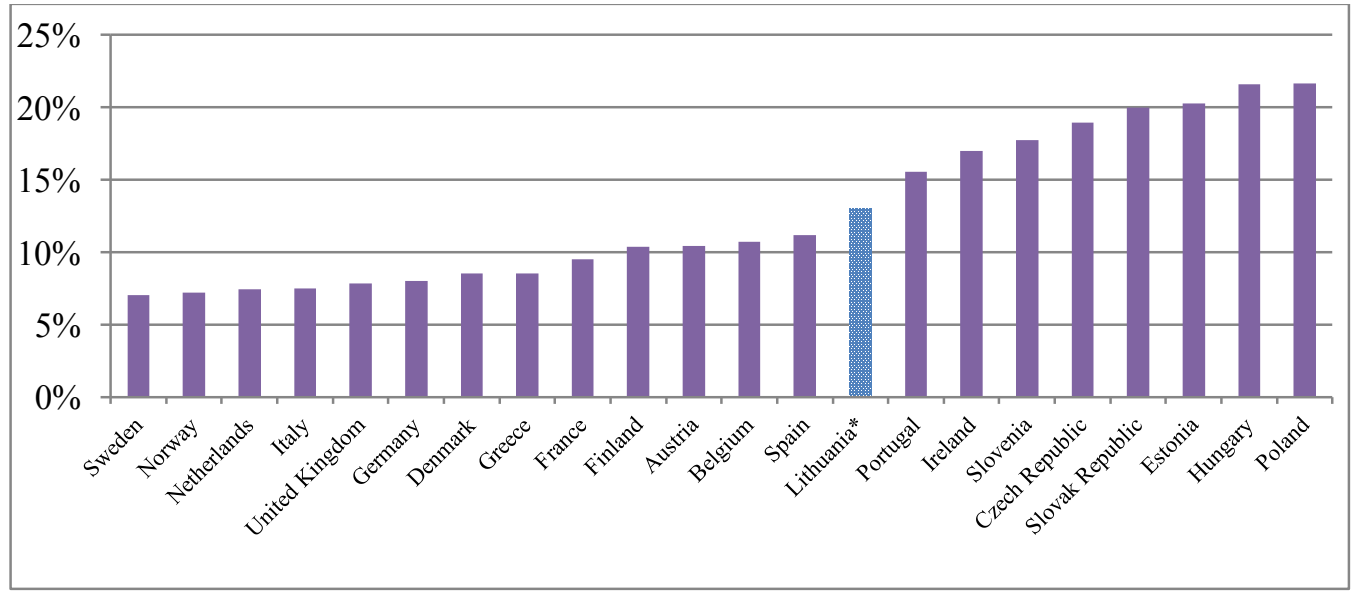

Source: Education at a Glance 2013 (OECD), own calculation. 
Note. Italy, Netherlands, Poland the rates were computed on the data from year 2009, Lithuania rates were computed on the data from year 2013.

Figure 2 shows the differences of the rate of private return on investment in human capital. The average private rate of return to education in the presented countries is 12.6 per cent. The largest returns on investment in human capital are in Hungary, Poland, Estonia and Slovakia. The high indicator of the rate of return to education shows that investment in education is very profitable in these countries. The higher the rate is, the more profitable the investment is. According to the data of the survey carried out by Eurostat in 2010, the average wage for people with higher education in Poland is 66.2 per cent higher than that of the individual who has acquired only secondary education. Thus, in the countries where there is a significant increase in wages and salaries due to the investment in higher education, the rate of return to education is higher. Meanwhile, the lowest rates of return are found in Sweden, Norway, the Netherlands, Italy and the United Kingdom.

When there is a lack of highly qualified employees in the country, their wages are increasing, while if there are too many of them, the employers use the situation and reduce wages, and then the return on investment in higher education is declining. On the basis of Eurostat data, in 2011 the percentage of citizens of the age of 18-74 years who have completed higher education was 33.8 per cent in the United Kingdom, 29.9 per cent in Sweden and 28.1 per cent in the Netherlands. While in Slovakia, Hungary and Poland, where the rate of return of education is the highest, the percentage of persons from 18 to 74 years of age with higher education was 16.7 per cent, 18.3 per cent and 20.8 per cent respectively.

The research conducted shows that the private rate of return on investment in education in Lithuania is 13.0 per cent. The private rate of return in Lithuania calculated in this research is much the same as the average rate of return in the countries presented in Figure 2, and it corresponds to the EU21 average rate of return pointed out by OECD (2013) during the period considered.

After comparing Lithuania's' and other countries' rates of return to investment in human capital, it is seen that private rate of return in Lithuania is similar to that of Spain $(11,2 \%)$. In neighboring countries - Poland and Estonia the return to investment in human capital is higher than 20 percent.

Comparing the rate of return to investment into human capital among European countries, the rate of return in Lithuania is two times higher than in Sweden, Norway, Netherlands, Italy and the United Kingdom. Although in comparison with Hungary, Poland and Slovakia the rates of return to investment in human capital is 1,6 times higher in these counties than in Lithuania.

The fact should be noted that the rate of return largely depends not only on direct costs or foregone earnings but on the assumptions made while calculating. Assessing the tuition fees, the rate of return is decreased up to 9,8 percent, because the sum of direct costs is directly increased by the tuition fee, which negatively influences the rate of return. The rate of return to investment in human capital in Lithuania is increased to 17,2 percent when the condition that the 
individual income can increase every year (e.g., due to experience gained, economic conditions change, etc.), is applied.

The return to higher education in European countries for men and women is presented in Figure 3. When evaluating the rates of return on investment in higher education for men and women, men's rates of return are usually higher. However, the data presented in Figure 3 shows that this is not so in all the countries.

Figure 3. Private rate of return to investment in human capital for a man and woman attaining tertiary education

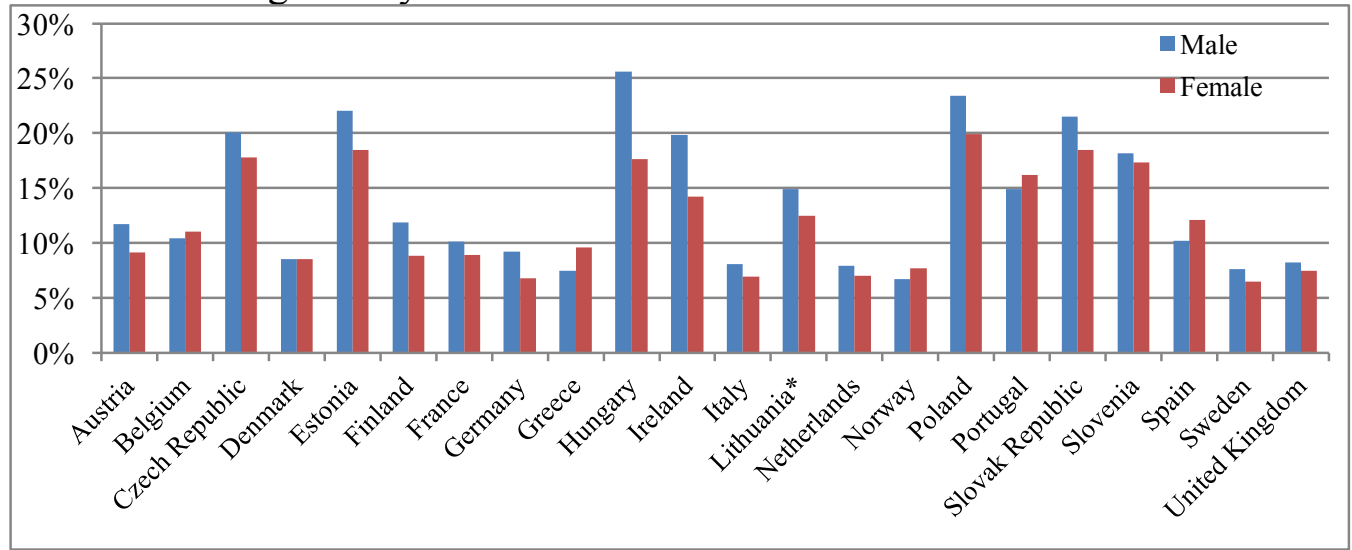

Source: Education at a Glance 2013 (OECD), own calculation.

Note. Italy, Netherlands, Poland the rates were computed on the data from year 2009, Lithuania rates were computed on the data from year 2013.

Only in 5 countries (Greece, Belgium, Portugal, Norway and Spain) are rates of return higher for women than for men. It also shows that the gender aspect for the rate of return of education almost does not affect Denmark - the rate of return is 8.5 per cent both for men and women in this country. The biggest differences between male and female rates of return of education were found in Hungary, Ireland, Poland and Estonia. In Hungary the rate of return of higher education for men is 8.0 per cent points higher than for women. This is the biggest difference between the rates of return of education for men and women in Europe. It should be noted that different rates of return between countries are determined not only by the differences in salaries. For example, according to S. Finardi, J. Fischer and P. Mazouch ${ }^{48}$, in Australia and Belgium taxes for men are higher than for women. Belgium and Spain have progressive tax rates of personal income tax. In Ireland special tax deductions are applied for married couples, because it is a country with a high share of religious residents and so on.

In some countries the rate of return of higher education for women is higher than for men, suggesting that gender inequality is declining. T. Pekkarinen ${ }^{49}$ notes that the rate of return of education for women slightly lags behind the rate of return for men, or even surpasses it, as the participation of women in the labour

${ }^{48}$ Savina Finardi, Jakub Fischer, Petr Mazouch, 'Private Rate of Return on Human Capital Investment in the Czech Republic: Differences by Study Fields' (2012) 49 (1) Statistika, Statistic and Economy journal 23-30.

${ }^{49}$ T. Pekkarinen, 'Gender Differences in Education` (2012) IZA Discussion Paper No. 6390. 
market has become the norm in many developed countries, women do not rush to get married any more, and the married women balance motherhood and career. The number of divorces has also increased. As a result, an increasing number of women invest in their human capital and seek to acquire higher education and gain a foothold in the labour market. In recent decades, the difference between men's and women's wages has declined sharply. The usual explanation is technological change that favors more educated workers, a shift of output toward more education-intensive goods, growing globalization that added to the demand for more skilled workers, and perhaps also to declining discrimination against women. There has also been an increase in the number of worked hours by married women ${ }^{50}$.

The calculations made show that man's rate of return on investment in human capital was 14,9 percent, while for an individual studying with a government grant for studies it was 1,9 percentage point higher than the calculated total (average women and men) rate of return. Man's internal rate of return was 11,4 percent, i.e. 3,5 percentage point lower, when the individual has to pay for his studies himself.

Women's rate of return to investment in human capital amounted to 12,5 percent and it was very close to the total average rate of return. And without government grant for studies the women's rate of return was 11,4 percent.

In summary it can be said that the investment in higher education is the most profitable in Poland, Hungary, Estonia, Slovakia, and a much lower rate of return of higher education is generated in Sweden, Norway, the Netherlands, Italy, the United Kingdom and Germany. In accordance with the indicator of the rate of return on investment in higher education Lithuania is roughly in the middle among the European countries.

\section{CONCLUSION}

Analysis of the concept of human capital has shown that human capital is a broad and multifaceted concept that consists of aggregate elements, which include: constantly gained and updated skills and knowledge, abilities (innate or acquired), the experience acquired through work, health and motivation. All of these elements help individuals to improve labour productivity.

Estimates of the rate of return of investment in human capital can be arrived at using different methods. This study was based on the private rate of return on investment in human capital using full discounting (or elaborate) method, based on individual age-earnings profiles (including foregone earnings) that vary over time.

After evaluation of the additional income which is due to higher human capital (i.e., higher education acquired), and direct and indirect (alternative) costs of investment in human capital it was found that the rate of return of investment in human capital, for those individuals whose studies are financed by the

${ }^{50}$ Gary. S. Becker, William H. J. Hubbard and Kevin M. Murphy, 'Explaining the Worldwide Boom in Higher Education of Women' MFI Working Paper Series No. 2010-09, 11. 
government, is 13 percent. The calculated private rate of return corresponds to the EU21 average rate of return pointed out by OECD (2013) during the period considered.

The calculations of the rate of return of investment in human capital has showed that in case the individual has to pay for higher education himself individual rate of return to investment into human capital is 9,8 percent. Therefore the tuition fee is increasing direct costs which negatively affect the rate of return.

After comparing Lithuania's' and other countries' rate of return to investment in human capital, it is seen that private rate of return in Lithuania is similar to Spain $(11,2 \%)$. Compared in neighboring countries - Poland and Estonia the return to investment in human capital is higher than 20 percent.

Comparing the rate of return to investment into human capital among European countries, the rate of return in Lithuania is two times higher than in Sweden, Norway, Netherlands, Italy, and United Kingdom. Although in comparison with Hungary, Poland and Slovakia the rate of return to investment in human capital is 1,6 times higher in these counties than in Lithuania.

Performed calculations have shown that man's rate of return on investment in human capital was 14,9 percent, while individual was studying with government grant for studies. Women's rate of return on investment in human capital amounted to 12,5 percent and it was very close to the total average rate of return, which amounted to 13 percent.

When evaluating the rates of return on investment in higher education for men and women, men's rates of return are usually higher. This study have shown that only in Greece, Belgium, Portugal, Norway and Spain are rates of return higher for women than for men. The gender aspect for the rate of return to education almost does not affect Denmark - the rate of return is 8,5 per cent both for men and women in this country. The biggest differences between male and female rates of return to education have been found in Hungary, Ireland, Poland and Estonia. It should be noted that different rates of return between countries are determined not only by the differences in salaries. 